eISSN: 09748369, www.biolmedonline.com

\title{
Interaction of simulated acid rain and seed gall nematode Anguina tritici on wheat
}

\author{
S Kausar*, ${ }^{a}$ AA Khan \\ ${ }^{*}$ Nematology Section, Indian Institute of Pulses Research, Kanpur-208024, India. \\ ${ }^{a}$ Environmental Botany Section, Department of Botany, Aligarh Muslim University, \\ Aligarh-202002, India. \\ *Corresponding author: samee.aina@gmail.com
}

\begin{abstract}
In the present study, Interaction of different doses of SAR (pH 3.0, 4.0 and 5.0) with different inoculum levels of $A$. tritici showed varied responses on wheat plant. Both SAR and $A$. tritici interacted antagonistically. The wheat plants inoculated with lower inoculum levels $(2,500$, and 5,000) and exposed with lower acidity level (5.0) were not affected in terms of plant growth, yield, photosynthetic pigments, seed carbohydrate, seed protein and leaf epidermal characteristics compared to un-inoculated and un-exposed plant. While, as acidity levels ( $\mathrm{pH} 4.0$ and 3.0$)$ were increased the suppressions in all above parameters were increased. However, nematodes were killed in all the doses of SAR.
\end{abstract}

Keywords: Acidity levels, antagonistically, nematode, interaction, suppression, wheat.

\section{Introduction}

The rain has been always very important for mankind as well as all flora and fauna. However, due to industrialization a huge amount of gaseous air pollutants i.e. NOx, SOx emitted in the atmosphere, react with water vapours present in atmosphere and precipitate in the form of acid rain. It adversely affects to plants, causing leaching of nutrients from the leaves, erosion of leaf cuticle leading to chlorosis and necrosis of the leaves and inhibition of growth (Foster, 1990; Heagle et al., 1883; Heck et al., 1986). The plant pathogens associated with them are also affected by acid rain. They may be interacted antagonistically or synergistically. Especially the aerial pathogens are antagonistically interacted with acid rain. Anguina tritici (Stainbuch) is an specific aerial nematode of wheat, feeds ectoparasitically on growing parts of the plant and lastly converts wheat grains into galls, caused enormous yield loss of wheat. The present study was carried out to evaluate the interactive effect of SAR and $A$. tritici on wheat crop.

\section{Materials and Methods}

Preparation of acidity level: Different dose of simulated acid rain ( $\mathrm{pH} 3.0,4.0$ and 5.0) were prepared by mixing conc. $1 \mathrm{~N} \mathrm{H}_{2} \mathrm{SO}_{4}$ and $1 \mathrm{~N}$ $\mathrm{HNO}_{3}(3: 1)$ in distilled water (D.W.) and pH level was maintained by measuring the solution with the help of digital $\mathrm{pH}$ meter.

Preparation of nematode inoculum: Seed galls were soaked in D.W. for $24 \mathrm{~h}$ and crushed gently with the help of needle. Thousands of second stage juveniles were emerged out in the water. The suspension containing juveniles were considered as nematode inoculum. From this suspension, different inoculum levels $(2,500$, 5,000 and 10,000) were prepared.

Culturing of plants and treatment: Seeds of wheat var. HD-2329 were surface sterilized $\left(0.01 \% \mathrm{HgCl}_{2}\right.$ solution). Five seeds were sown in each clay pot filled with autoclaved soil (sandy loam and cow dunk in 3:1). After emergence of seedlings, thinning was done to retain only one seedling/pot. After 10 days seedlings were inoculated with the different inoculum levels $(2,500,5,000$ and $10,000 \mathrm{~N})$ separately. Total 30 pots (10 treatments including control set $X 3$ replicates) were prepared. The plants were showered with different acidity levels $(\mathrm{pH} 3.0$, 4.0 and 5.0) separately inside exposure chamber through nozzle spray for about $4 \mathrm{~mm}$ rain. The exposures were given twice in a week till 100 days. Before termination of plants photosynthetic pigments were estimated according the method of MacLachlan and Zalik (1963) and leaf epidermal characteristics were studied by the method of Ghause and Yunus 
(1972). After 120 days plants were uprooted and growth, yield, seed carbohydrate (Yih and Clark, 1963; Dubois et al., 1956) and seed protein (Lowery et al., 1951) were determined.

Data analysis: The data were analyzed statistically for significance by the method of Gomez and Gomez (1984). Standard deviation and percent decrease over control were also calculated.

\section{Results}

All doses of SAR were harmful to A. tritici and wheat plant. The SAR exposure $(\mathrm{pH} 3.0$, and 5.0) produced visible symptoms like chlorosis, necrosis and leaf tip burning. All plant growth (length, fresh wt. and dry wt. of 100 grains) parameters were significantly reduced $(P=0.05$, $P=0.01)$ in all treatments compared to control set (Table 1). The reduction in all parameters was directly proportional to acidity and inoculum levels. Generally, nematodes were killed by SAR except in treatments with lower dose and higher inoculum levels $(5.0+5,000$ and $5.0+10,000)$, where few galls were formed.

The data summarized in table 2 also indicate that photosynthetic pigments (chl a, chl $\mathrm{b}$, and carotenoids) seed protein (soluble and insoluble) and seed carbohydrate (soluble and insoluble) were also significantly inhibited in all treatments compared to control set. Highest reduction in all biochemical parameters were observed at $3.0+10,000$ inoculum level.

Leaf stomata and trichomes were also affected by combined exposure of different doses of SAR with different inoculum levels. Number, length and width of stomata and length of stomata aperture of both surfaces were directly proportional to acidity levels and inoculum levels. As acidity levels and inoculum levels were increased, the size and number were decreased. While width of stomata aperture was widen with the increase of acidity levels.

\section{Discussion}

Higher acidity levels of SAR (pH 3.0, 4.0) caused chlorotic, necrotic and leaf tip burning symptoms. While at lower acidity level ( $\mathrm{pH} 5.0)$, no symptoms were observed. It was due to less sensitivity of monocots to acid rain based on visible symptoms (Singh and Agrawal, 2004). Both SAR and $A$. tritici interacted antagonistically. Therefore, intensity of disease was less in plants inoculated with nematodes and exposed to simulated acid rain compared to nematode alone inoculated treatments. Therefore, it can be implied that acid rain stressed wheat plants are likely to suffer less pathogenic damage caused by $A$. tritici. Possibly, the two adverse factors: gaseous pollutants and aerial nematode interacted antagonistically and improved slightly the plant growth and yield. However, the improvements were not significant when compared to control because SAR directly caused enough damage to wheat plants. The seed gall formation was also not observed at higher acidity levels as all juveniles were killed. Because this is an aerial parasite, which remains in very exposed position to polluted atmosphere. Further, they were dependent on the epidermal cells for their host parasite relationship. But SAR might have injured the epidermal cells and reduced the leaf surface are available for feeding sites of larvae. Heagle (1982); Khan and Kausar (2005); Khan and Khan (1994); Singh et al, (1993) also observed similar effect of acid rain on several other obligate fungal and nematode parasites.

In exposed plants, irrespective of inoculum levels, leaf pigments were reduced in comparison to unexposed plants. However, the reduction was inoculum and SAR dose dependent. Reduced chlorophyll of the leaves and lowered enzymatic activities in exposed plants would have caused reduction in plant growth, yield and carbohydrate contents. Protein contents of wheat seeds were reduced in all exposed treatments in comparison to unexposed plants. $\mathrm{SAR}+A$. tritici exhibited antagonistic interaction in their effect on protein content of seeds. Direct interference of the air pollutants in the metabolic activities of plants related to protein synthesis and indirect effects by causing poor plant growth possibly reduced protein contents (Khan and Malhotra, 1983; Singh, 1989; Singh et al., 1993).

Stomata have been found to be adversely affected by SAR and $A$. tritici alone and in combination and were correlated with the extant of the leaf injury. Fewer stomata with reduced size revealed the self defense of the wheat plant to check the entry of gaseous pollutants in leaf. However, wide apertures of stomata were due to SAR injury to epidermal and guard cells (Khan and Khan, 1994). 
Table 1: Interactive effect of different levels of SAR and A. tritici on plant growth and yield of wheat.

\begin{tabular}{|c|c|c|c|c|c|c|c|c|c|c|c|c|}
\hline \multirow{3}{*}{$\begin{array}{c}\text { Treatment } \\
(\mathrm{pH}+\text { Inoculum })\end{array}$} & \multicolumn{8}{|c|}{ Plant Growth } & \multicolumn{4}{|c|}{ Yield } \\
\hline & \multicolumn{2}{|c|}{$\begin{array}{l}\text { Length } \\
\text { (cm) }\end{array}$} & \multicolumn{2}{|c|}{$\begin{array}{l}\text { Fresh wt. } \\
\text { (g) }\end{array}$} & \multicolumn{2}{|c|}{$\begin{array}{l}\text { Dry wt. } \\
\text { (g) }\end{array}$} & \multirow[t]{2}{*}{$\begin{array}{c}\text { Tillers } \\
\text { no. }\end{array}$} & \multirow{2}{*}{$\begin{array}{c}\text { Leaf } \\
\text { area } \\
\left(\mathrm{cm}^{2}\right)\end{array}$} & \multirow{2}{*}{$\begin{array}{c}\text { Ear } \\
\text { length } \\
(\mathrm{cm})\end{array}$} & \multirow{2}{*}{$\begin{array}{c}\text { No. of } \\
\text { Grains } \\
\text { lear }\end{array}$} & \multirow{2}{*}{$\begin{array}{c}\text { Wt. of } \\
100 \\
\text { grain } \\
\text { s } \\
\text { (g) }\end{array}$} & \multirow{2}{*}{$\begin{array}{c}\text { No. of } \\
\text { galls/ } \\
\text { ear }\end{array}$} \\
\hline & Shoot & Root & $\overline{\text { Shoot }}$ & Root & Shoot & Root & & & & & & \\
\hline Control & 66.4 & 20.7 & 21.6 & 1.84 & 5.10 & 0.415 & 3.8 & 35.2 & 11.8 & 36 & $\begin{array}{l}4.5 \\
7\end{array}$ & - \\
\hline $5.0+2,500$ & 62.5 & 18.7 & 19.6 & 1.68 & 4.26 & 0.364 & 3.2 & 31.7 & 10.9 & 31 & $\begin{array}{l}3.7 \\
1\end{array}$ & - \\
\hline $5.0+5,000$ & 60.9 & 17.8 & 18.9 & 1.52 & 3.76 & 0.362 & 2.9 & 29.3 & 9.3 & 27 & $\begin{array}{l}3.6 \\
8\end{array}$ & 2 \\
\hline $5.0+10,000$ & 58.1 & 15.9 & 14.4 & 1.45 & 3.30 & 0.354 & 2.7 & 28.0 & 9.2 & 24 & $\begin{array}{l}3.2 \\
1\end{array}$ & 3 \\
\hline $4.0+2,500$ & 58.0 & 16.3 & 15.6 & 1.27 & 3.59 & 0.308 & 2.7 & 27.0 & 9.3 & 26 & $\begin{array}{l}3.1 \\
8\end{array}$ & - \\
\hline $4.0+5,000$ & 57.6 & 16.1 & 15.5 & 1.25 & 3.51 & 0.302 & 2.7 & 24.3 & 9.3 & 26 & $\begin{array}{l}2.9 \\
2\end{array}$ & - \\
\hline $4.0+10,000$ & 56.4 & 15.3 & 15.0 & 1.92 & 3.29 & 0.300 & 2.5 & 24.2 & 9.0 & 24 & $\begin{array}{l}2.8 \\
8\end{array}$ & - \\
\hline $3.0+2,500$ & 52.1 & 14.0 & 12.7 & 0.91 & 3.12 & 0.235 & 2.3 & 22.2 & 7.5 & 22 & $\begin{array}{l}2.5 \\
8\end{array}$ & - \\
\hline $3.0+5,000$ & 52.1 & 14.0 & 12.7 & 0.91 & 3.09 & 0.235 & 2.2 & 21.5 & 7.4 & 21 & $\begin{array}{l}2.5 \\
8\end{array}$ & - \\
\hline $3.0+10,000$ & 51.8 & 13.8 & 12.7 & 0.90 & 3.04 & 0.235 & 2.2 & 20.3 & 7.3 & 21 & $\begin{array}{l}2.5 \\
8\end{array}$ & - \\
\hline$P=0.05$ & 2.79 & 1.28 & 1.38 & 0.11 & 0.59 & 0.034 & 0.38 & 2.42 & 0.58 & 3.4 & $\begin{array}{l}0.5 \\
7\end{array}$ & \\
\hline$P=0.01$ & 3.82 & 1.76 & 1.89 & 0.15 & 0.81 & 0.047 & 0.52 & 3.32 & 0.79 & 4.6 & $\begin{array}{l}0.7 \\
8\end{array}$ & \\
\hline
\end{tabular}

Each value is a mean of three replicates. 
Table 2: Interactive effect of different levels of SAR and A. tritici on biochemical properties of wheat.

\begin{tabular}{|c|c|c|c|c|c|c|c|c|}
\hline \multirow{2}{*}{$\begin{array}{l}\text { Treatment } \\
\text { (pH + } \\
\text { Inoculum) }\end{array}$} & \multicolumn{4}{|c|}{$\begin{array}{l}\text { Photosynthetic Pigments } \\
\text { (mg g }{ }^{-1} \text { leaf fresh wt.) }\end{array}$} & \multicolumn{2}{|c|}{$\begin{array}{c}\text { Carbohydrate } \\
(\%)\end{array}$} & \multicolumn{2}{|c|}{$\begin{array}{c}\text { Protein } \\
(\%)\end{array}$} \\
\hline & $\overline{\text { Chl a }}$ & ChI b & $\begin{array}{c}\text { Total } \\
\text { chl } \\
(\mathrm{a}+\mathrm{b})\end{array}$ & Carotenoids & Soluble & Insoluble & Soluble & Insoluble \\
\hline Control & 1.120 & 0.551 & 1.671 & 0.569 & 17.74 & 60.28 & 4.29 & 8.33 \\
\hline $5.0+2,500$ & 0.992 & 0.501 & 1.493 & 0.511 & 16.76 & 57.85 & 3.91 & 7.99 \\
\hline $5.0+5,000$ & 0.979 & 0.487 & 1.466 & 0.502 & 16.21 & 57.25 & 3.85 & 7.87 \\
\hline $5.0+10,000$ & 0.932 & 0.457 & 1.389 & 0.452 & 15.84 & 56.28 & 3.34 & 7.22 \\
\hline $4.0+2,500$ & 0.830 & 0.417 & 1.247 & 0.417 & 14.56 & 54.52 & 2.92 & 6.85 \\
\hline $4.0+5,000$ & 0.826 & 0.415 & 1.241 & 0.416 & 14.47 & 54.39 & 2.88 & 6.77 \\
\hline $4.0+10,000$ & 0.805 & 0.408 & 1.213 & 0.407 & 14.44 & 53.84 & 2.78 & 6.65 \\
\hline $3.0+2,500$ & 0.678 & 0.350 & 1.028 & 0.304 & 11.94 & 44.49 & 2.14 & 4.82 \\
\hline $3.0+5,000$ & 0.667 & 0.343 & 1.010 & 0.303 & 11.93 & 44.30 & 2.07 & 4.82 \\
\hline $3.0+10,000$ & 0.660 & 0.340 & 1.00 & 0.300 & 11.95 & 44.15 & 2.08 & 4.74 \\
\hline$P=0.05$ & 0.091 & 0.031 & 0.125 & 0.039 & 0.68 & 1.73 & 0.24 & 0.21 \\
\hline$P=0.01$ & 0.124 & 0.043 & 0.172 & 0.053 & 0.94 & 2.37 & 0.33 & 0.29 \\
\hline
\end{tabular}

Each value is a mean of three replicates. 
Table 3: Interactive effect of different levels of SAR and A. tritici on leaf epidermal characters of wheat.

\begin{tabular}{|c|c|c|c|c|c|c|c|c|}
\hline \multirow{3}{*}{$\begin{array}{l}\text { Treatment } \\
\text { (pH+Inoculum }\end{array}$} & \multirow{3}{*}{$\begin{array}{c}\text { Leaf } \\
\text { Surface }\end{array}$} & \multicolumn{5}{|c|}{ Stomata } & \multicolumn{2}{|c|}{ Trichome } \\
\hline & & \multirow[t]{2}{*}{$\begin{array}{c}\text { Number } \\
\left(\mathrm{mm}^{-2}\right)\end{array}$} & \multicolumn{2}{|c|}{$\begin{array}{l}\text { Size of stomata } \\
(\mu \mathrm{m})\end{array}$} & \multicolumn{2}{|c|}{$\begin{array}{c}\text { Size of stomatal aperture } \\
(\mu \mathrm{m})\end{array}$} & \multirow[t]{2}{*}{$\begin{array}{l}\text { Number } \\
\left(\mathrm{mm}^{-2}\right)\end{array}$} & \multirow[t]{2}{*}{$\begin{array}{l}\text { Length } \\
(\mu \mathrm{m})\end{array}$} \\
\hline & & & Length & Width & Length & Width & & \\
\hline \multirow[t]{2}{*}{ Control } & Abaxial & $82 \pm 2.00$ & $16.6 \pm 0.16$ & $10.37 \pm$ & $11.7 \pm$ & 4.15 & $12 \pm 1.00$ & 1.4 \\
\hline & Adaxial & $70 \pm$ & $16.4 \pm 0.10$ & $10.29 \pm 0.03$ & 11.5 & 3.9 & 0.53 & 1.2 \\
\hline \multirow[t]{2}{*}{$5.0+2,500$} & & & & 4 & & & 2.08 & \\
\hline & & 5. & & 10.08 & & & 1.16 & \\
\hline \multirow[t]{2}{*}{$5.0+5,000$} & Abaxial & $76 \pm$ & $15.3 \pm 0.20$ & 10.04 & $11.1 \pm 0.17$ & 4.16 & $13 \pm 2.08$ & 3.5 \\
\hline & Adaxial & $62 \pm 1.53$ & $15.2 \pm 0.10$ & $9.96 \pm$ & $11.0 \pm 0.38$ & $4.05 \pm$ & $11 \pm 1.16$ & $224 \pm 2.0$ \\
\hline \multirow[t]{2}{*}{$5.0+10,000$} & Abaxial & $70 \pm 1.53$ & $15.1 \pm 0.21$ & $9.92 \pm$ & $10.9 \pm 0.12$ & $4.10 \pm 0.02$ & $12 \pm 1.00$ & $256 \pm 1.6$ \\
\hline & Adaxial & $59 \pm 2.00$ & $15.0 \pm 0.23$ & $9.86 \pm 0.05$ & $10.8 \pm 0.27$ & $4.00 \pm 0.03$ & 2.08 & $218 \pm 2.0$ \\
\hline \multirow[t]{2}{*}{$4.0+2,500$} & Abaxial & $68 \pm$ & $14.5 \pm 0.12$ & 9.70 & .15 & 4.6 & $11 \pm 1.53$ & $242 \pm 3.5$ \\
\hline & Adaxial & $57 \pm 2.00$ & $14.2 \pm 0.21$ & $9.58 \pm 0.02$ & 10.7 & 4.52 & $10 \pm 1.00$ & $200 \pm 2.2$ \\
\hline \multirow[t]{2}{*}{$4.0+5,000$} & Aba & & 1 & .0 & & 4.56 & 00 & \\
\hline & Adaxial & $56 \pm$ & $14.1 \pm 0$ & 9.57 & & 4.4 & $9 \pm 1.16$ & $192 \pm 2.0$ \\
\hline \multirow[t]{2}{*}{$4.0+10,000$} & Abaxial & $62 \pm 1.16$ & $14.2 \pm 0.15$ & $9.56=$ & 10.5 & $4.5^{\prime}$ & $10 \pm 0.58$ & $228 \pm 1.2$ \\
\hline & Adaxial & $52 \pm 1.00$ & $13.9 \pm 0.12$ & $9.42 \pm$ & 10.2 & 4.4 & $9 \pm 2.08$ & $180 \pm 3.5$ \\
\hline \multirow[t]{2}{*}{$3.0+2,500$} & Abaxial & $62 \pm 1.00$ & $13.5 \pm 0.29$ & $8.84 \pm 0.02$ & $9.9 \pm 0.15$ & $5.10 \pm 0.02$ & $9 \pm 1.16$ & $226 \pm 2.1$ \\
\hline & Adaxial & $51 \pm 1.16$ & $13.3 \pm 0.20$ & $8.76 \pm 0.02$ & $9.7 \pm 0.21$ & $4.98 \pm 0.02$ & $8 \pm 2.08$ & $174 \pm 1.5$ \\
\hline \multirow[t]{2}{*}{$3.0+5,000$} & Abaxial & $62 \pm 0.58$ & $13.5 \pm 0.10$ & $8.82 \pm 0$. & & $5.08 \pm 0.02$ & $9 \pm 1.53$ & $224 \pm 3.1$ \\
\hline & Adaxial & $51 \pm$ & $13.2 \pm 0.15$ & $8.75 \pm 0.02$ & $9.7 \pm 0.12$ & 4.95 & $8 \pm 1.16$ & $172 \pm 2.1$ \\
\hline $3.0+10,000$ & & $\begin{array}{l}60 \pm 2.89 \\
48 \pm 1.16\end{array}$ & $\begin{array}{l}13.5 \pm 0.10 \\
13.2 \pm 0.12\end{array}$ & $\begin{array}{l}8.78 \pm \\
8.72 \pm\end{array}$ & & $\begin{array}{l}5.06 \\
4.94\end{array}$ & $\begin{array}{l}9 \pm 1.00 \\
8 \pm 2.08\end{array}$ & $\begin{array}{l}220 \pm 2.0 \\
168 \pm 3.1\end{array}$ \\
\hline$P=0.05$ & Abaxial & 3.6 & 0.73 & 0.14 & 0.42 & 0.08 & 0.93 & 8.34 \\
\hline$P=0.05$ & Adaxial & 4.2 & 0.64 & 0.18 & 0.36 & 0.12 & 0.91 & 7.21 \\
\hline
\end{tabular}

Each value is a mean of three replicates; \pm standard deviation. 
Increment in number and size of trichomes at low level were apparently the morphological adaptations of the plant to defend from the pollutants. Trichomes are known to offer outer line of physical defense against the toxic gases (Levin, 1973). Similar responses of trichomes on leaf surface of Abelmoschus esculantus, chickpea, Croton bonplandianus, eggplant, Euphorbia hirta, lentil, and Psidium guajava were recorded by Ghause and Khan (1978), Gupta and Ghause (1987), Khan and Khan (1994, 1997) and Singh (1989). The interactive effects of SAR and $A$. tritici on leaf epidermal characteristics of wheat were antagonistic. The inhibitory effect of the SAR exposures might have resulted from direct toxic effect on $A$. tritici.

\section{Conclusion}

As $A$. tritici caused great loss of wheat crop. From the present study, it was revealed that lower acidity level ( $\mathrm{pH}$ 5.0) was able to suppress the $A$. tritici effect with less damage of the wheat crop. However, at higher acidity levels, $(\mathrm{pH} 3.0$ and 4.0) nematodes were checked but it also adversely affected to wheat plant.

\section{References}

Dubois M, Gilles K A, Hemilton, J K, Rebers P A, Smith F, 1956. A calorimetric method for determination of sugars and related substances. Analytical Chemistry, 28: 350-356.

Foster J R, 1990. Influence of $\mathrm{pH}$ and plant nutrients status on ion fluxes between tomato plants and simulated acid mists. New Phytology, 116: 475-485.

Ghause A K M, Khan M A U, 1978. Environmental pollution and epidermal structure in Psidium guajava L. In the Proceeding of International Symposium Hyderabad on Environmental Agents and Their Biological Effects.

Ghause A K M, Yunus M, 1972. Preparation of epidermal peels from leaves of gymnosperms by treatments with $40 \% \mathrm{HNO}_{3}$. Stain Technology, 47: 322-324.

Gomez K A, Gomez A A, 1984. Statistical Procedures for Agricultural Research. J. Wiley and Sons. New York.

Gupta M C, Ghause A K M, 1987. The effects of coalsmoke pollutants on the growth, yield and leaf epidermal features of Abelomoschus esculantus Monach. Environmental Pollution, 43: 263.
Heagle A S, 1982. Interaction between air pollutants and plant parasitic diseases. In: Effects of Gaseous Air Pollutions in Agriculture. Butterworth Scientific London. M.H. Unsworth and D.P. Ormord (eds.) p 33348.

Heagle A S, Philback R B, Brewer PF, Farrel R E, 1983. Response of soybeans to simulated acid rain in the field. Journal of Environment. Quality, 12: 538-543.

Heck W W, Heagle A S, and Shriner, D.S. 1986. Native Crops and Forests. Air Pollution. Academic Press, New York. A.S. Stern (ed.). Effect on vegetation. 6: 247-350.

Kausar S, Khan A A, Raghav D, 2006. Interaction of sulphur dioxide and seed gall nematode, Anguina tritici on wheat. Journal of Food Agriculture and Environment, 3 (3 \& 4): 130-132.

Khan A A, Malhotra S S, 1983. Protein biosynthesis in Jack pine and its inhibition by sulphur dioxide. Phytopathology. 22: 1325-1328.

Khan A A, Kausar S, 2005. Study of sulphur dioxide effects on seed gall nematode, $A$. tritici on wheat. In: National Symposium on Recent Advances and Research in Indian Nematology. IARI, New Delhi, p 5.

Khan M R, Khan M W, 1994. Effect of simulated acid rain and root-knot nematode on tomato. Plant Pathology, 43: 41-49.

Khan M R, Khan M W, 1997. Effect of root-knot nematode, Meloidogyne incognita on the sensitivity of tomato to sulphur dioxide and ozone. Environmental Experimental Botany, 38: 117-130.

Khan M R, Khan M W, Singh K, 1997. Management of root-knot disease of tomato by the application of fly ash in soil. Plant Pathology, 46: 33-43.

Levin D A, 1973. Role of trichomes in plant defense. Quarterly Review of Biology 48: 1-16.

Likens G E, 1976. Acid precipitation. Chemical Engineering Newsletter, 54: 29-44.

Lowery $\mathrm{O} \mathrm{H}$, Rosebrough N J, Farr A L, Randall R J, 1951. Protein measurement with folin reagent. Journal of Biological Chemistry 193: 265-275.

MacLachlan, S, Zalik S, 1963. Plastid structure, chlorophyll concentration and free amino acid composition of chlorophyll mutant of barley. Canadian Journal. of Botany, 41: 1053-1062.

Singh S K, 1989. Studies on interaction of air pollutants and root-knot nematodes on some pulse crops. Ph. D Thesis, Aligarh Muslim University, Aligarh, India. 
Singh B, Agrawal M, 2004. Impact of simulated acid rain in growth and yield of two cultivars of wheat. Water Air and Soil Pollution, 152: 71-80.

Singh K, Khan M W, Khan M R, 1993. Combined effect of sulphur dioxide, a root-knot nematode and a root-nodule bacterium on some biochemical processes in pea. Chemistry of Environment. Res, 2: 55-61.
Steinbuch J G, 1799. Das Graslchan. Vibrio agrostis. Naturforscher. 28: 233-259.

Yih R Y, Clark H E, 1965. Carbohydrate and protein content of boron-deficient tomato root tips in relation to anatomy and growth. Plant Physiology, 40: 312315. 